


\section{Uranium pollution in South Africa: past research and future needs}

\section{Onečišćenje uranijem u Južnoafričkoj Republici: prošla istraživanja i buduće potrebe}

Extracting gold for over a century from the Witwatersrand basin in South Africa as the largest known deposit on Earth, inadvertently also brought large amounts of radioactive and chemotoxic uranium $(\mathrm{U})$ into densely populated environments. With well over 6000 million t of tailings, the Witwatersrand goldfields contain more uraniferous mine waste than all other U-producing countries worldwide combined, exposing millions of mainly impoverished residents to contaminated air, water, soil and food. Yet, to date, no systematic effort has been made to quantify reliably the extent of the problem and assess associated health risks for the entire region. Acknowledging that any concerted strategy for addressing the $U$ legacy requires a scientific base, this paper briefly describes how research on U pollution in South Africa developed, which topics were covered and some of the gaps. Based on this, a radio-ecological approach is proposed to be followed for systematically addressing the problem and arriving at a sound scientific understanding of where $\mathrm{U}$ originates, how it migrates through the environment and what the associated health risks are.

Key words: uranium, contamination, mining, health risk, radio-ecology
Vađenje zlata u razdoblju duljem od stoljeća iz bazena Witwatersranda u Južnoafričkoj Republici, najvećega poznatog nalazišta na Zemlji, nenamjerno je u gusto naseljen okoliš unijelo velike količine radioaktivnog $\mathrm{i}$ kemotoksičnog uranija (U). S više od šest milijardi tona otpada witwatersrandska zlatna polja sadržavaju više uranijeve rudničke jalovine od svih drugih proizvođača uranija na svijetu zajedno, izlažući milijune uglavnom siromašnoga stanovništva onečišcenu zraku, vodi, tlu i hrani. No do danas nije bilo sustavnih napora da se pouzdano kvantificira opseg problema i procijene s njime povezani zdravstveni rizici za cijelu regiju. Prihvaćajući činjenicu da svaka usklađena strategija usmjerena na uranijeve posljedice zahtijeva znanstvenu podlogu, u radu se ukratko opisuju razvoj istraživanja onečišćenja uranijem u Južnoafričkoj Republici, obrađene teme te neke od propuštenih. $\mathrm{Na}$ temelju toga preporučuju se radioekološki pristup sustavnoj obradi problema te pronalaženje pouzdanoga znanstvenog razumijevanja podrijetla uranija, njegova kretanja okolišem i utvrdivanje s njim povezanih zdravstvenih rizika.

Ključne riječi: uranij, onečišćenje, rudarenje, zdravstveni rizici, radioekologija

\footnotetext{
* This paper was presented on one of the recent meetings (2012-2014) of the Commission for Water Sustainability of the International Geographical Union (IGU).

* Rad je predstavljen na jednom od skupova Komisije za vode Međunarodne geografske unije (IGU) održanih u razdoblju 2012.-2014.
} 


\section{Introduction}

Of the 90 naturally occurring elements of the periodic table that make up the universe, uranium $(\mathrm{U})$ is not only the heaviest one found in measurable quantities on Earth but also the one that has perhaps shaped the face of planet Earth most profoundly. Containing the only natural isotope able to sustain a nuclear chain reaction, it is the radioactive decay of ${ }^{235} \mathrm{U}$ and its daughter elements that still provide the geothermal energy used inside the Earth for melting rock into magma, creating and moving whole continents and driving earthquakes, tsunamis and volcanic eruptions that still profoundly shape our environment.

In South Africa, more than in any other country worldwide, humans removed $U$ from the safe geological underground and introduced the radioactive and chemically toxic metal into their own environment, simply by continuously extracting gold from the world's largest known deposit in the Witwatersrand basin. Since both elements are exceptionally heavy, they have historically been deposited in identical environments, resulting in most gold reefs (as the ore bodies are termed in SA) also containing appreciable amounts of U. Except for a 30-year period during the Cold War (early 1950s to the early 1980s) when U was produced as a by-product of gold for military use in atomic weapons of the USA, most of the U was dumped as waste onto the large tailings deposits of the gold mines. These deposits, locally known as "slimes dams" or "tailings dams" are now defining features of the urban landscape of cities like Johannesburg that owe their very existence to the mines.

Compared to other commodities, the mining of gold creates an exceptionally large amount of waste, simply because of gold's low abundance that, while making it precious, also requires large volumes of rock to be mined before sufficient quantities are obtained. Combined with the exceptionally long mining period of nearly 130 years in the Witwatersrand, this created by far the largest volume of uraniferous mining waste deposited anywhere in the world. Covering a large footprint area of some $400 \mathrm{~km}^{2}$,

\section{Uvod}

Od devedeset elemenata periodnog sustava koje nalazimo u prirodi $\mathrm{i}$ od kojih je izgrađen svemir uranij (U) nije samo najteži koji u mjerljivim količinama pronalazimo na Zemlji nego je i onaj koji je možda najviše utjecao na izgled planeta. Kako sadržava jedini prirodni izotop sposoban za podržavanje nuklearne lančane reakcije, upravo radioaktivni raspad ${ }^{235} \mathrm{U}$ i njegovih produkata i danas u unutrašnjosti Zemlje stvara geotermalnu energiju koja stijene tali u magmu te tako gradi i pokreće cijele kontinente i uzrokuje potrese, cunamije i vulkanske erupcije koji uvelike utječu na izgled okoliša.

U Južnoafričkoj Republici", više nego u bilo kojoj drugoj zemlji na svijetu, ljudi su iskapali uranij te iz podzemlja unosili radioaktivan i kemijski toksičan metal u vlastiti okoliš jednostavnim vađenjem zlata iz najbogatijega poznatog nalazišta na svijetu u bazenu Witwatersranda. Kako su oba elementa osobito teška, u geološkom vremenu su se nataložila u identičnim okolišima koji su stvorili većinu zlatnih grebena (kako se u Južnoafričkoj Republici nazivaju ležišta rudače) s mjerljivim količinama uranija. Osim tridesetogodišnjeg razdoblja tijekom Hladnoga rata (od početka pedesetih do početka osamdesetih godina 20. stoljeća), kad je uranij kao nusproizvod zlata upotrebljavan u vojne svrhe $\mathrm{u}$ atomskom naoružanju $\mathrm{SAD}-\mathrm{a}$, većina se uranija kao jalovina odbacivala na velika odlagališta rudnika zlata. Ta odlagališta, koja se lokalno nazivaju „sluzavim nasipima” ili ,jalovinskim nasipima”, danas su prepoznatljiva obilježja urbaniziranoga krajolika gradova poput Johannesburga koji svoje postojanje zahvaljuju upravo rudnicima.

U usporedbi s drugim sirovinama rudarenje zlata stvara iznimno veliku količinu otpada, jednostavno zato što zbog male količine zlata, koja je i razlog njegove vrijednosti, zahtijeva vađenje velikih količina stijena kako bi se dobilo dovoljno zlata. Zbog iznimno dugog razdoblja rudarenja u Witwatersrandu od gotovo 130 godina tako je nastala daleko najveća količina odloženog uranijem onečišćenog otpada na svijetu. Prekrivajući veliku površinu od oko $400 \mathrm{~km}^{2}$, ta jalovina sadržava više od šest mili-

\footnotetext{
* Službeni naziv države je Republika Južna Afrika no u prijevodu članka se zbog praktičnih razloga koristi u hrvatskom jeziku češći naziv Južnoafrička Republika i njegova skraćenica JAR.
} 
these tailings contain well over 6000 million $t$ of finely ground mine waste, most of which still contains $\mathrm{U}$ in its original ore-levels (Chamber of Mines, 1999). In contrast to many other major U producers located in remote and scarcely populated areas such as the Australian outback, the Arctic Circle of Canada and deserts in the USA, nearly all of the uraniferous tailings in South Africa are deposited in densely populated regions with millions of people living in the immediate vicinity. While $U$ grades vary significantly between slimes dams, on average, gold tailings in SA contain some $100 \mathrm{~g} \mathrm{U}$ per ton of tailings amounting to well over $600,000 \mathrm{t}$, which are exposed to a chemically aggressive atmosphere with an abundance of free oxygen and water (Schoenfeld et al. 2014). A map depicting the gold mining areas of the Witwatersrand basin is displayed in Fig. 1. jardi tona finomljevena rudničkog otpada, od kojeg većina i dalje sadržava uranij u izvornoj koncentraciji (Rudarska komora JAR-a, 1999). Za razliku od brojnih drugih velikih proizvođača uranija koji se nalaze u izoliranim i slabo naseljenim područjima poput unutrašnjosti Australije, kanadskoga polarnoga kruga i pustinja u SAD-u, gotovo sva uranonosna jalovina u Južnoafričkoj Republici odlaže se u gusto naseljenim područjima s milijunima ljudi u neposrednoj blizini. Iako se količina uranija jako razlikuje među nasipima, zlatna jalovina u JAR-u u prosjeku sadržava oko $100 \mathrm{~g}$ uranija po toni jalovine, a to znači da je više od 600.000 tona izloženo kemijski agresivnoj atmosferi s mnogo slobodnoga kisika i vode (Schoenfeld i dr., 2014). Karta područja rudarenja zlata u bazenu Witwatersranda prikazana je na sl. 1 .

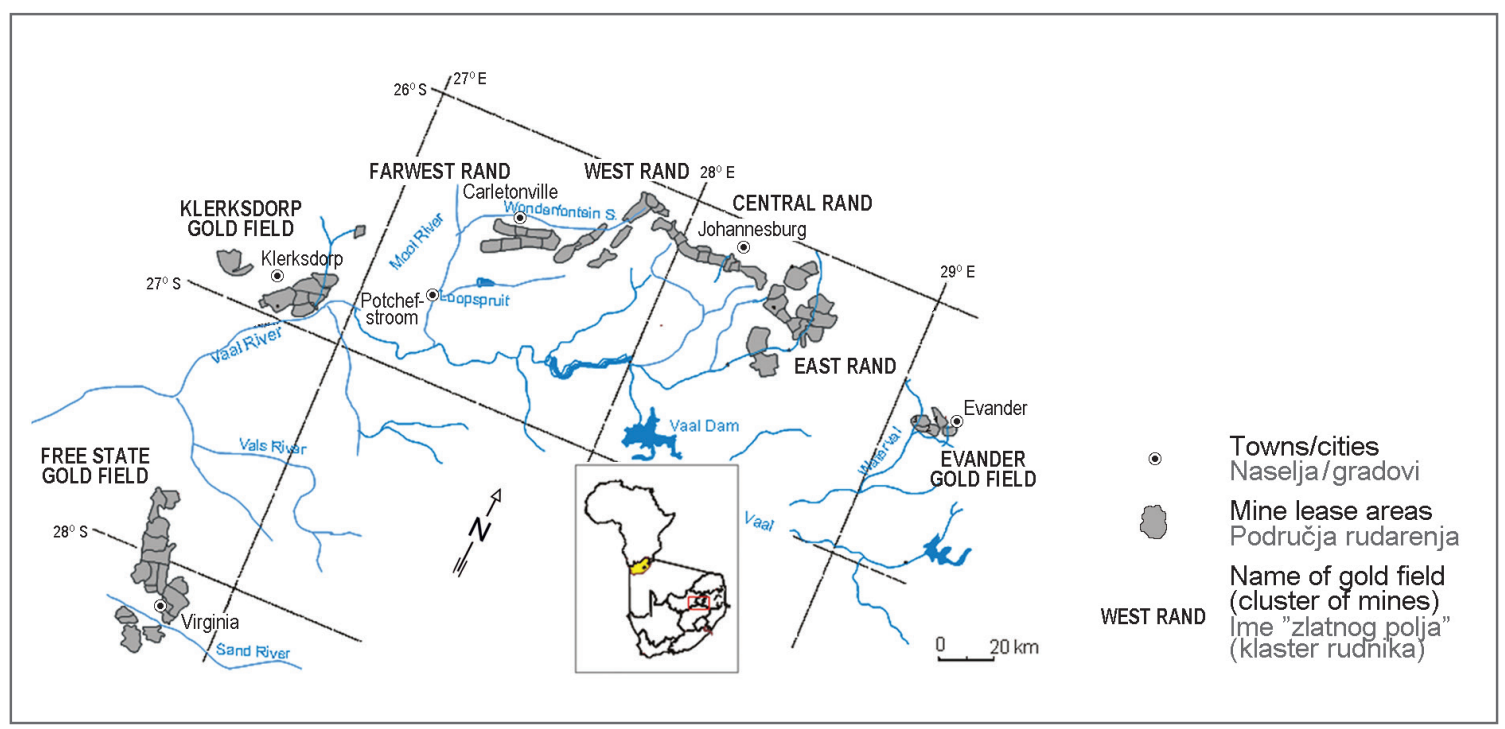

Fig. 1 Gold mining areas of the Witwatersrand basin in South Africa (based on mine lease areas)

SI. 1. Rudnici zlała u bazenu Witwatersrand u Južnoafričkoj Republici (na temelju rudničkih koncesija)

As a result, much of the $U$ contained in the tailings is mobilised and moves - dissolved in porewater - along with seepage escaping from the waste deposits, into the aquatic environment. Linear transport in receiving streams and rivers rapidly dissipates $U$ in the environment, exposing areas well outside the mining regions to the toxic metal. Public streams used by - often informal and poverty stricken - residents for domestic purposes, including drinking and cooking, often contain U levels
Uranium pollution in South Africa: past research and future needs

Onečišćenje uranijem u Južnoafričkoj Republici: prošla istraživanja $\mathrm{i}$ buduće potrebe
Zbog toga se mnogo uranija iz jalovine mobilizira, otapa u podzemnoj vodi te iz odlagališta dospijeva u vodeni okoliš. Linearni transport tekućicama brzo širi uranij i izlaže toksičnome metalu područja koja su udaljena od rudarskih. U javnim vodotokovima koje za potrebe svojih kućanstava, između ostaloga kao pitku vodu i vodu za kuhanje, upotrebljavaju često neuki i siromašni stanovnici uranij je nerijetko daleko iznad dopustivih granica, iako se 
GEOGRAFSKI

GLASNIK

77/2,33-53 (2015.) well above permissible levels, even though guideline values vary significantly between countries and legislation.

Given that recent findings suggest a much wider spectrum of chemo- and radiotoxicity related to $U$, it is paramount to assess the possibly associated risks mining-related $U$ pollution may pose to the health of millions of exposed people.

Placed into a global context, a brief review on the history and development of researching $U$ pollution in South Africa is provided, including references to the media that have played and continue to play an important watchdog role in this field.

Based on this review, the paper identifies existing knowledge gaps and proposes a radio-ecological approach for comprehensively assessing health risks. In order to support the latter, crucial aspects of where $\mathrm{U}$ originates, and how and along which pathways it is dissipated throughout the environment are discussed. This, in turn, will inform an improved ranking of contaminated sites according to health risk potential and allow prioritising remediation.

\section{Reviewing research on U pollution in South Africa - an overview}

The global context: Compared to decades of state-sponsored, mostly confidential research into the uses of $U$ for nuclear weapons and power generation from the early 1940s on to the end of the Cold War, investigations of environmental and health aspects are a rather recent phenomenon that started in earnest in the 1980s in the USA, as part of the country's efforts to remediate the legacy of decades of uranium mining and milling activities (UMTRA $^{1}$ ) (Waggit, 1994).

The environmental research into $U$ received a major boost in the 1990s with the reunification of Germany, as a condition of which the country assumed the responsibility of remediating the largest U-mining region in Europe - the formerly Soviet-controlled Wismut area that produced most of the $\mathrm{U}$ used in the atomic weapons programme of okvirne vrijednosti uvelike razlikuju među zemljama i zakonodavstvima.

Kako nedavna istraživanja upućuju na mnogo širi spektar kemotoksičnosti i radiotoksičnosti povezanih s uranijem, iznimno je važno procijeniti moguće rizike rudarskog onečišćenja uranijem na zdravlje milijuna izloženih ljudi.

Postavljen u širi kontekst, u nastavku je sažetak povijesti i razvoja istraživanja onečišćenja uranijem u Južnoafričkoj Republici, uključujući informacije o medijima koji su imali, a i dalje imaju važnu ulogu u nadzoru na tom području.

$\mathrm{Na}$ temelju tog sažetka u radu se ističu manjkavosti u poznavanju i predlaže radioekološki pristup sveobuhvatnoj procjeni zdravstvenih rizika. Upravo radi zdrastvenih rizika razmatraju se ključni aspekti podrijetla uranija te putevi i načini njegovog širenja okolišem. Tako će se dobiti informacije o redoslije$\mathrm{du}$ onečišćenih područja u odnosu na potencijalni zdrastveni rizik i omogućiti ustanovljavanje prioriteta u poboljšavanju situacije.

\section{Pregled istraživanja onečišćenja uranijem v Južnoafričkoj Republici}

Globalni kontekst: U usporedbi s desetljećima državno financiranih, uglavnom tajnih istraživanja iskorištavanja uranija za nuklearno oružje i proizvodnju električne energije od početka četrdesetih godina 20. stoljeća do završetka Hladnoga rata, istraživanja ekoloških i zdravstvenih aspekata zapravo su počela tek nedavno, osamdesetih u SAD-u kao dio napora te zemlje da ispravi posljedice desetljećâ rudarenja i prerade uranija $\left(\mathrm{UMTRA}^{1}\right)\left(\mathrm{Wa}^{-}\right.$ ggit, 1994).

Ekološka istraživanja uranija velik su poticaj dobila devedesetih ponovnim ujedinjenjem Njemačke, na temelju odgovornosti koju je ta država preuzela kako bi popravila uvjete u najvećoj europskoj regiji za dobivanje uranija - području pod upravom tvrtke Wismut**, nekoć pod sovjetskim nadzorom, u kojem se vadio najveći dio uranija upotrijeblje-

1 UMTRA - Uranium Mills and Tailings Remediation Act

1 UMTRA - Uranium Mills and Tailings Remediation Act, Zakon o uklanjanju posljedica onečišćenja u tvornicama uranija i uranijevoj jalovini.

** Wismut - tvrtka koja je upravljala rudnicima i preradom uranija u južnom dijelu nekadašnje Istočne Njemačke (Njemačka Demokratska Republika). 
the Soviet Union. In an environmental rehabilitation programme of unprecedented scale in terms of resources and funding, the German Government allocated over Deutschmark 15 bn (equivalent to $€$ $7.5 \mathrm{bn}$ ) to remediate Wismut legacy sites. This was scientifically complemented by a number of German universities and research institutions, among them the oldest university with a mining programme - the Bergakademie in Freiberg (Freiberg University on Mining and Technology) - which established an international conference series on Uranium Mining and Hydrogeology (UMH) that soon became one of the most renowned global forums on the topic. After the collapse of the Iron Curtain, efforts also increased in other former countries of the former Eastern Bloc to remediate legacy sites including $\mathrm{U}$ mines, $\mathrm{U}$ production sites, etc. (e.g. Cerne et al., 2010, Zoriy et al. 2010).

South Africa: When, in 2007, the SA Government declared uranium a "strategic mineral" and soon thereafter embarked on a nuclear expansion programme with announced intentions, once again, to become a global supplier of $\mathrm{U}$, the country continued a tradition of several decades (Olivier, 2007; Zhuwakinyu, 2007). Initiated by the Manhattan Project in the USA to build the first atomic bomb, large-scale production of $U$ as a much needed core component for this endeavour started in SA in 1951, after a government-sponsored large-scale $\mathrm{U}$-programme provided the required infrastructure and resources (Taverner, 1957). During the next decades of the ensuing Cold War, South Africa became the fourth largest U-producer worldwide after the USA, Canada and East Germany. However, out-and-out U-mines remained the exception as most of the $\mathrm{U}$ in South Africa was produced as a by-product of deep level gold mines, since the auriferous reefs often also contained significant $U$ grades.

Falling U-prices in the 1980s led to a significant drop in U-production and the radioactive heavy metal was again dumped along with tailings on the many slimes dams, as happened during the 65 years before the start of the South African U-programme. Since the discovery of gold in the Witwatersrand basin in 1886, gold mines produced well over 6 bn $\mathrm{t}$ of gold tailings covering some $400 \mathrm{~km}^{2}$ (Robb nog za proizvodnju nuklearnog oružja u Sovjetskom Savezu. U programu ekološkog oporavka u do tada nezabilježenim razmjerima resursa i financiranja, njemačka je vlada uložila više od petnaest milijardi maraka (što odgovara 7,5 milijardi eura) u uklanjanje onečišćenjâ Wismutovih pogona. To je znanstveno popratilo nekoliko njemačkih sveučilišta i istraživačkih instituta, među njima i najstarije rudarsko sveučilište Bergakademie Freiberg, koje je organiziralo niz međunarodnih simpozija $R u d a-$ renje $i$ hidrogeologija uranija (Uranium Mining and Hydrogeology, UMH), koji su se uskoro pokazali jednim od najvažnijih globalnih foruma na tu temu. Poslije pada željezne zavjese i u drugim su se državama bivšega Istočnog bloka pojačali napori za uklanjanje industrijskih onečišćenja, među njima i rudnika uranija, tvornica za proizvodnju uranija itd. (npr. Cerne i dr., 2010; Zoriy i dr., 2010).

Južnoafrička Republika: Kad je 2007. Vlada JAR-a proglasila uranij „strateškim mineralom” i uskoro započela proširivanje nuklearnog programa s objavljenom namjerom da ponovno postane važan dobavljač uranija na svijetu, nastavila je tradiciju koja je trajala nekoliko desetljeća (Olivier, 2007; Zhuwakinyu, 2007). Započeta u SAD-u Projektom Manhattan za izgradnju prve atomske bombe, proizvodnja uranija na veliko kao središnjeg dijela tog programa u JAR-u je počela 1951. pošto je opsežan program koji je financirala Vlada ponudio potrebnu infrastrukturu i resurse (Taverner, 1957). Tijekom sljedećih desetljeća Hladnoga rata Južnoafrička Republika postala je četvrti najveći proizvođač uranija na svijetu, poslije SAD-a, Kanade i Istočne Njemačke. No rudnici namijenjeni samo dobivanju uranija u Južnoafričkoj su Republici ostali iznimkom jer je većina elementa bila nusproizvod zlata koje se vadilo iz dubokih rudnika.

Pad cijena uranija u osamdesetima uzrokovao je i pad njegove proizvodnje, a radioaktivni teški metal ponovno se počeo odlagati na brojnim odlagalištima jalovine, baš kao i tijekom 65 godina prije početka južnoafričkog programa proizvodnje uranija. Od otkrića zlata u bazenu Witwatersrandu 1886. rudnici zlata proizveli su više od šest milijardi tona zlatne jalovine koja prekriva oko $400 \mathrm{~km}^{2}$ (Robb i Robb, 1998). S procijenjenim sadržajem od oko 100 g uranija po toni (CoM, 1999) ta zlatna jalovina
Uranium pollution in South Africa: past research and future needs

Onečišćenje uranijem u Južnoafričkoj Republici: prošla istraživanja $i$ buduće potrebe 
HRVATSKI

GEOGRAFSKI

GLASNIK

77/2,33-53 (2015.) and Robb, 1998). With an estimated average of approximately $100 \mathrm{~g} \mathrm{U}$ per ton (CoM, 1999) these gold tailings contain higher $U$ levels than many genuine U-tailings elsewhere (e.g. in the Wismut region: $70-90 \mathrm{~g} / \mathrm{t}$ ) and contain some $600,000 \mathrm{t}$ of $\mathrm{U}$ - nearly 4 times the amount exported during the Cold War (ca. 150.000 t). Given the huge amount of uraniferous tailings spread over large areas, it is no surprise that many rivers and aquifers in mining regions are now affected by $\mathrm{U}$ pollution (e.g. Winde and Sandham, 2004).

However, it was only recently that the mining industry at large acknowledged that there is, in fact, a problem and - at least partly - took on some responsibility. The fact that $\mathrm{U}$-production in SA, since its inception, was surrounded by secrecy may have contributed to the culture of denial well into the 1990s. This was despite the fact that suspicions on the adverse effects of U-polluted mine water had been raised by farmers as early as in 1967 (Stoch and Retief, 1967) and had been confirmed by even earlier Government investigations (Jordaan et al., 1960). These allegations were finally followed up by a Government-led investigation conducted by the national veterinary research station at Onderstepoort, which analysed various animals for radionuclides that kept the (inconclusive) results confidential (Die Komitee oor die Gehalte van Water an die Verre-Wesrand, 1971).

While the mining industry traditionally enjoyed a very close relationship with Government that often resulted in the rather soft policy on enforcing existing legislation, this changed, somewhat, after the democratic elections in 1994. However, a few years before the new political dispensation became a reality in South Africa a number of internal investigations into radioactive pollution by gold mines were conducted by the mining and nuclear industry. This included studies on radioactive mine water pollution by the Chamber of Mines Research Organisation (COMRO) in 1985 (COMRO 1985), and uranium analyses of mine water from various mines in the upper Wonderfonteinspruit catchment (Dorling 1988). The Atomic Energy Corporation of SA Ltd (AEC), later renamed into Nuclear Energy Corporation of South Africa, (NECSA) investigated the concentrations of ${ }^{226} \mathrm{Ra}$ in tailings as well as nearby streams in the East, Central and sadržava više uranija nego u drugim pravim zlatnim jalovinama u drugim dijelovima svijeta (na Wismutovu području između $70 \mathrm{i} 90 \mathrm{~g} / \mathrm{t}$ ) te otprilike 600.000 t uranija - gotovo četiri puta više nego što je izvezeno tijekom Hladnoga rata (oko 150.000 t). Kad se uzme u obzir golema količina uranonosne jalovine raširene na velikom području, ne čudi da su brojne rijeke i podzemni vodonosnici u rudarskim područjima onečišćeni uranijem (npr. Winde i Sandham, 2004).

No tek je nedavno rudarska industrija priznala da problem zapravo postoji te je - barem djelomice - preuzela i dio odgovornosti za njega. To što je proizvodnja uranija u Južnoafričkoj Republici od samoga početka bila zaštićena velom tajne možda je sve do kasnih devedesetih pridonosilo kulturi negiranja, usprkos tome što su se sumnje u nepovoljne učinke rudničke vode onečišćene uranijem pojavile još davne 1967. (Stoch i Retief, 1967) i bile potvrđene još ranijim Vladinim istraživanjima (Jordaan i dr., 1960). Te su tvrdnje naposljetku potaknule vlasti da pokrenu istraživanje u organizaciji državne veterinarske istraživačke postaje u Onderstepoortu, koja je različite životinje analizirala na radionuklide, ali su (neuvjerljivi) rezultati ostali tajni (Die Komitee oor die Gehalte van Water aan die Verre-Wesrand, 1971).

Rudarska industrija tradicionalno je održavala vrlo uske veze s Vladom, što je često za posljedicu imalo izrazito meku politiku nadzora provođenja zakonâ, no to se poslije demokratskih izbora 1994. u određenoj mjeri promijenilo. Ali nekoliko godina prije nego što je u Južnoafričkoj Republici uspostavljeno novo političko vodstvo, rudarska i nuklearna industrija provele su niz internih istraživanja radioaktivnog onečišćenja rudnika zlata. Među njima je bilo i istraživanje radioaktivnog onečišćenja vode Istraživačke organizacije Rudarske komore (Chamber of Mines Research Organisation, COMRO) iz 1985. (COMRO, 1985), analize uranija u vodi iz nekoliko rudnika u gornjem dijelu poriječja Wonderfonteinspruita (Dorling, 1988). Korporacija za atomsku energiju Južnoafričke Republike (The Atomic Energy Corporation of SA Ltd, AEC), poslije preimenovana u Korporaciju za nuklearnu energiju Južnoafričke Republike (Nuclear Energy Corporation of South Africa, NECSA) istražila je koncentraci- 
West Rand (de Jesus et. al 1987). A systematic survey conducted by the COMRO in 1990 established for a number of mines across the entire Witwatersrand basin significantly elevated uranium levels in mine water (Pulles 1991). A spot sample conducted later at Deelkraal Gold Mine found significantly elevated uranium levels in urine of mine workers (Deelkraal GM, 1995).

The first non-confidential report on the matter by Funke (1990) provided an overview on the uranium pollution potential of gold mines in South Africa, without indicating concrete $U$ levels. This report was followed up with a study funded by the Water Research Commission (WRC) jointly conducted by the Earth and Environmental Technology Department of the AEC and zoologists of the Rand Afrikaans University (Bain et al. 1994). The study analysed several gold mining areas in the East, Central and West Rand for $\mathrm{U}$ and ${ }^{226} \mathrm{Ra}$ pollution of water and soils, as well as the associated migration of uranium along the food chain, sampling various vegetables, fish, cattle tissue, cow milk, cattle dung, aquatic vegetation and water birds. Apart from determining concentration ratios (also known as "transfer factors") for the water-soil, fodder-cattle, fodder-milk and fodder-dung pathways, the report also calculated the associated effective radiation dose for the various exposure pathways and found that none exceeded the $0.25 \mathrm{mSv} / \mathrm{a}$ limit applied for radiation from a single source (Bain et al. 1994).

Specifically addressing pollution by gold mining activities, two regional surveys of radioactive pollution of rivers in and around the Witwatersrand goldfields were now also conducted by the Government (Department of Water Affairs and Forestry, DWAF), confirming that a number of rivers and streams were indeed significantly contaminated (Faanhof et al., 1995; Kempster et al., 1996). Based on these two surveys, in late 1996, the largest study on U-pollution to date was launched by the then Minister of Water Affairs Mr. Kader Asmal, focussing on the Wonderfonteinspruit catchment where the first complaints on adverse effects were reported in the 1960s (IWQS, 1999).

Interestingly, at around the same time, a WRC study into health effects of naturally elevated je ${ }^{226} \mathrm{Ra}$ u jalovini i obližnjim vodotokovima u Istočnom, Središnjem i Zapadnom Randu (de Jesus i dr., 1987). Podrobnim istraživanjem koje je COMRO proveo 1990. u nekoliko su rudnika u cijelom bazenu Witwatersranda pronađene znatno povećane razine uranija u rudničkoj vodi (Pulles, 1991). Uzorak poslije uzet iz rudnika zlata Deelkraal pokazao je veliko povećanje razine uranija u mokraći rudarâ (Deelkraal GM, 1995).

Prvo izvješće koje nije bilo tajno (Funke, 1990) nudi pregled opasnosti od onečišćenja uranijem u rudnicima zlata u Južnoafričkoj Republici, ali ne navodi konkretne količine uranija. To je izvješće popratilo istraživanje koje je financirala Komisija za istraživanje voda (Water Research Commission, WRC), a zajednički su ga proveli Odjel za geološku i ekološku tehnologiju AEC-a i zoolozi sa Sveučilišta Rand Afrikaans (Bain i dr., 1994). U istraživanju su se analizirali onečišćenje vode i tla uranijem $\mathrm{i}^{226} \mathrm{Ra}$ u nekoliko zlatonosnih rudarskih područja u Istočnom, Središnjem i Zapadnom Randu te s tim povezano kretanje uranija kroz hranidbeni lanac, $s$ uzorcima iz povrća, ribe, tkiva goveda, kravljeg mlijeka, govedskog izmeta, vodenog raslinja i vodenih ptica. Osim određivanja omjera koncentracija (tzv. transfernih čimbenika) za vodu i tlo, hranu i goveda, hranu i mlijeko te hranu i izmet izvješće je izračunavalo i s tim povezane efektivne doze zračenja za različite kanale izlaganja te je ustanovilo da nijedan nije premašio granicu od $0,25 \mathrm{mSv} / \mathrm{a}$ važeću za zračenje iz jednog izvora (Bain i dr., 1994).

Posebno se usredotočujući na onečišćenje aktivnostima rudarenja zlata, Vlada je provela dva regionalna istraživanja radioaktivnog onečišćenja rijeka na zlatnim poljima Witwatersranda i oko njih (Odjel za vodoprivredu i šumarstvo, Department of Water Affairs and Forestry, DWAF) te ustanovila da je nekoliko rijeka i potoka doista znatno onečišćeno (Faanhof i dr., 1995; Kempster i dr., 1996). $\mathrm{Na}$ temelju tih dvaju istraživanja tadašnji ministar za vodoprivredu Kader Asmal pokrenuo je potkraj 1996. do tada najveće istraživanje onečišcenja uranija usredotočeno na poriječje Wonderfonteinspruita, u kojem su šezdesetih zabilježene prve pritužbe na neželjene posljedice (IWQS, 1999).

Zanimljivo, otprilike istodobno u sušnome ovčarskom području provincije Sjeverni Cape (oko
Uranium pollution in South Africa: past research and future needs

Onečiščenje uranijem u Južnoafričkoj Republici: prošla istraživanja $\mathrm{i}$ buduće potrebe 
GEOGRAFSKI

GLASNIK

77/2,33-53 (2015.)
U-levels was initiated in an arid sheep farming area of the Northern Cape (around the town of Pofadder), which finally established a geo-statistical link between U-levels in borehole water consumed by farmers, and the occurrence of haematological abnormalities serving as proxy for leukaemia from which an unnaturally high number of people suffered in the area (Toens et al., 1998).

Although some individuals served on the steering committees of both projects (i.e. the WFS and Pofadder study) there is no record of any cross-communication let alone collaboration between the two research teams. This is puzzling as both studies investigated a nearly identical problem. Although the alarming findings of the Pofadder study were published a year before the IWQS report was released, the latter contains not a single reference to this highly relevant document. A contributing factor to this could have been that the title of the original Pofadder project was changed in such a way that crucial keywords such as "uranium" and "leukaemia" disappeared from the title of the final publication, rendering any library search for these key topics (at the time) unsuccessful (Toens et al., 1998).

A letter from the principle researcher of the Pofadder project, Dr. Dennis Toens to Kader Asmal, requesting urgent intervention received a lukewarm response, stating that no action could be taken as the prevalence of leukaemia in the region could also be caused by a range of other factors including toxic agro-chemicals, contaminated dust etc. not explored in the study. While three independent follow-up studies meanwhile confirmed the elevated levels of $\mathrm{U}$ in the region (Wullschleger et al., 1998; Sekoko et al., 2005; van Wyck and Coetzee, 2006), no investigation into possible causes of the leukaemia cluster have been attempted in the past 16 years since the Toens report was published. Despite being plagued by conflicting views of the various interest groups represented at the steering committee (Stoch, E. J., McLaren, A., personal communication, 1999), the IWQS study in the WFS marked the beginning of systematic scientific efforts to investigate the alleged pollution problem caused by gold mining. To this date, the study remains the single most extensive and comprehensive investigation on the topic in South Africa, based on the amount of analysed samples and time period covered. grada Pofaddera) pokrenuto je WRC-ovo istraživanje o zdravstvenim učincima prirodno povišenih razina uranija, kojim je nedvojbeno ustanovljena geostatistička veza između razine uranija u vodi iz bušotina koju su upotrebljavali farmeri i hematoloških poremećaja kao indikatora leukemije od koje je obolijevao neprirodno velik broj stanovnika u tom području (Toens i dr., 1998).

Iako su neke osobe bile u upravnim odborima obaju projekata (tj. istraživanja WFS i Pofadder), nema nikakvih zabilježenih podataka o međusobnoj komunikaciji, a kamoli suradnji među dvama istraživačkim timovima. To doista iznenađuje jer su oba istraživanja proučavala gotovo istovjetni problem. Iako su zabrinjavajuća otkrića istraživanja Pofadder objavljena godinu dana prije IWQS-ova izvješća, ovo posljednje uopće ne spominje taj toliko važni dokument. Čimbenik koji je tome svakako mogao pridonijeti jest promjena izvornog naslova projekta Pofadder, tako da su iz njega nestale ključne riječi poput „uranija” i „leukemije”, pa je knjižnična pretraga za tim temama (u to vrijeme) bila neuspješna (Toens i dr., 1998).

Pismo dr. Dennisa Toensa, vodećeg znanstvenika projekta Pofadder, Kaderu Asmalu kojim je zahtijevao hitnu intervenciju dobilo je neuvjerljiv odgovor u kojem se tvrdilo kako se na učestalost leukemije u tom području ne može djelovati jer je mogu uzrokovati i brojni drugi čimbenici, među njima i toksična poljoprivredna sredstva, onečišćena prašina itd., kojima se istraživanje nije bavilo. Iako su tri neovisna naknadna istraživanja u međuvremenu potvrdila povišene razine uranija na tom području (Wullschleger i dr., 1998; Sekoko i dr., 2005; van Wyck i Coetzee, 2006), u proteklih šesnaest godina od objavljivanja Toensova izvješća nije obavljeno nijedno istraživanje o mogućim uzrocima leukemijskih bolesti. Usprkos poteškoćama zbog suprotstavljenih stavova različitih interesnih skupina predstavljenih u upravnom odboru (Stoch, E. J., McLaren, A., osobno priopćenje, 1999), istraživanje IWQS u WFS-u označilo je početak sustavnih znanstvenih pokušaja istraživanja navodnog onečišćenja uzrokovanog rudarenjem zlata. To je istraživanje po količini analiziranih uzoraka i razdoblju koje je obuhvatilo ostalo do danas jedino široko i sveobuhvatno istraživanje te teme u Južnoafričkoj Republici. 
Since then there have been over 40 related studies conducted in the Wonderfonteinspruit (WFS) catchment alone, many encountering similar obstacles caused by conflicting interests. One particular report (Coetzee et al., 2006) was, for example, embargoed by intervention of a particular mining house and a subsequent moratorium imposed on the report by the then Department for Minerals and Energy (DME). The report was published with a two year delay only after repeated requests from an environmental activist and a journalist (personal communication Liefferink, M., CEO of the FSE and Tempelhoff. E., journalist 2005). When the report was eventually released it was hailed as first evidence of the "democratisation of science in SA" (personal communication, Turton, A., CSIR researcher, 2006).

However, the National Nuclear Regulator (NNR) represented on the Steering Committee of the project insisted on including a disclaimer in the published version in which it disagreed with the risk assessment methodology and undertook to conduct its own investigation. After considerable delay, this investigation finally got underway in 2006 when a German company (Brenk Systemplanung) conducted a radiological risk assessment on behalf of the NNR (Barthel, 2007, 2011). The fact that this report (known as "Brenk Report" even though its author was Dr. R. Barthel) established even higher risks quotients triggered a public outcry accompanied by often sensationalising media reports in which headline phrases such as Death in the water, Lives at risks as mines coin it, Health nightmare and Toxic tsunami were used, the latter latching onto emotions the real tsunami in Indonesia had triggered just a few months before (Avni, 2007; Tempelhoff, 2007a; Beega, 2008a; Stuijt, 2008; Jordan 2009). The fact that the author of the Brenk Report was subsequently prevented from presenting an already accepted paper at the Enviromin Conference to be held in SA a few weeks later certainly did not help to instil public trust in open and transparent governance (Barthel et al., 2007).

After a shortened and edited version of the original report was finally released by the NNR mid-2007 on their website, a range of follow-up investigations started, concentrating on possible risk
Otada je samo u izravnom poriječju Wonderfonteinspruita (WFS) provedeno više od četrdeset istraživanja na tu temu, a mnoga su se morala suočiti sa sličnim preprekama uzrokovanim sukobljenim interesima. Na jedno je izvješće (Coetzee i dr., 2006) primjerice poslije intervencije jedne rudarske tvrtke stavljena zabrana, uz moratorij na izvješce tadašnjeg Ministarstva za minerale i energiju (Department for Minerals and Energy, DME). Izvješće je objavljeno tek dvije godine poslije, nakon brojnih zahtjeva jednoga ekološkog aktivista i novinara (osobno priopćenje, Liefferink, M., generalni direktor FSE-a, i Tempelhoff, E., novinar, 2005). Kad je izvješće naposljetku objelodanjeno, smatralo ga se prvim dokazom „demokratizacije znanosti u Južnoafričkoj Republici" (osobno priopćenje, Turton, A., istraživač CSIR-a, 2006).

No Državna nuklearna regulatorna agencija (National Nuclear Regulator, NNR) s predstavnikom u upravnom odboru projekta inzistirala je da objavljena inačica sadržava i upozorenje da se Agencija ne slaže s metodologijom procjene rizika te će provesti vlastito istraživanje. Poslije odugovlačenja to je istraživanje počelo 2006., kad je njemačka tvrtka (Brenk Systemplanung) za račun NNR-a obavila procjenu radiološkog rizika (Barthel, 2007, 2011). To što je izvješće (poznato kao „Izvješće Brenk Report”, iako joj je autor bio dr. R. Barthel) ustanovilo još veće rizike izazvalo je javne prosvjede popraćene nerijetko senzacionalističkim napisima u medijima s naslovima poput „Smrt u vodi”, „Životi u opasnosti dok se rudnici bogate”, „Zdravstvena noćna mora” i "Toksični cunami”, a posljednji se nadovezao na katastrofu pravog cunamija u Indoneziji, koji se dogodio samo nekoliko mjeseci prije (Avni, 2007; Tempelhoff, 2007a; Beega, 2008a; Stuijt, 2008; Jordan 2009). To što je autor Brenkova izvješća odmah spriječen da predstavi već prihvaćeni rad na simpoziju Enviromin koji se nekoliko tjedana poslije trebao održati u JAR-u, svakako nije javnosti ulilo povjerenje u otvorenu i transparentnu vlast (Barthel i dr., 2007).

Pošto je NNR sredinom 2007. na svojim internetskim stranicama objavio skraćenu i prerađen inačicu izvornog izvješća, pokrenut je niz dopunskih istraživanja koja su se usredotočila na mogući rizik u prehrambenom lancu, koji je u Brenkovu
Uranium pollution in South Africa: past research and future needs

Onečiščenje uranijem u Južnoafričkoj Republici: prošla istraživanja $i$ buduće potrebe 
GEOGRAFSKI

GLASNIK

77/2,33-53 (2015.) via the food chain as the main exposure pathway identified in the Brenk Report (e.g. McCrindle, 2008; Hamman, 2012). Unfortunately, and this is stated with all due respect, many of these studies were conducted in an uncoordinated and ad hoc manner by activists, residents and academics who were often not familiar with this specialised field of science, nor with the study area, this resulting in contradictory and/or questionable findings that added to, rather than eliminated the confusion surrounding the issue. Associated newspaper articles claimed, for example, that thousands of cattle had to be shot because of pollution, that exposure to dust while driving through the area could lead to cancer and that extreme levels of $U$ were found in vegetable grown in the area (Tempelhoff, 2007b, 2008a/b; Botha 2008), triggering responses by readers and journalists that questioned these statements and even alleged deliberate distortion (e.g. Van Heerden, 2007; Engelbrecht, 2008; Martins, 2008; Tempelhoff, 2008c; Stoch, 2008; Louw, 2009a).

Following the Brenk Report and the recommended need for intervention, a combined initiative by the DWAF and the NNR for rehabilitating the WFS catchment got underway with the aim of mitigating radiological health risks in the Wonderfonteinspruit catchment area (WCA).

In a first step, a Specialists Task Team (STT) was appointed consisting of members from South Africa, Canada and the USA tasked to compile a so-called "hot-spot map" indicating the sites needing most urgent intervention. The map was eventually produced by the author employing a specifically developed risk assessment methodology based on a combination of the extent of contamination and the associated probability of exposure to members of the general public (Winde, 2008). However, instead of the STT jointly following up on how to address the identified 34 "hot spots", the consulting company that was originally tasked merely to facilitate easier project administration took over and, in its own capacity, effectively stopped further progress by compiling a final report (Remediation Action Programme, RAP) that later proved to be inadequate and was eventually rejected by the Steering Committee (Iliso, 2008; Louw, 2009b).

In order to overcome this set-back, a new initia- izvješću identificiran kao glavni čimbenik izlaganja (npr. McCrindle, 2008; Hamman, 2012). Na nesreću, a to ističemo uz dužno poštovanje, mnoga su od tih istraživanja neusklađeno i ad hoc provodili aktivisti, stažisti i članovi akademske zajednice neupućeni u tu specijalističku granu znanosti i područje na kojem se istraživalo, pa su rezultati nerijetko bili kontradiktorni i/ili upitni, a sve je to povećavalo, a ne uklonilo zbrku u vezi s tim pitanjem. U novinskim člancima o toj temi pisalo je primjerice da je zbog onečišćenja moralo biti ustrijeljeno na tisuće grla stoke, da je izloženost prašini tijekom vožnje kroz to područje mogla uzrokovati rak te da su u povrću uzgajanom u tom kraju pronađene ekstremno visoke količine uranija (Tempelhoff, 2007b, 2008a/b; Botha 2008), što je potaknulo odgovore čitateljâ i novinarâ koji su takve tvrdnje smatrali upitnima te su čak sumnjali u namjerno izvrtanje podataka (npr. Van Heerden, 2007; Engelbrecht, 2008; Martins, 2008; Tempelhoff, 2008c; Stoch, 2008; Louw, 2009a).

Poslije Brenkova izvješća i preporučenih interventnih mjera zajedničkom inicijativom DWAF-a i NNR-a počelo je čišćenje razvođa WFS-a kako bi se uklonila radiološka opasnost za zdravlje u cijelom području Wonderfonteinspruita (WCA).

U prvoj je fazi Specijalistička skupina (Specialists Task Team, STT) s članovima iz Južnoafričke Republike, Kanade i Sjedinjenih Američkih Država trebala izraditi tzv. „kartu vrućih točaka” s mjestima na kojima je intervencija bila najhitnija. Kartu je autor naposljetku načinio služeći se posebno razvijenom metodologijom procjene rizika utemeljenom na kombinaciji postojećih onečišćenja i s njim povezane vjerojatnosti izlaganja stanovništva tih područja (Winde, 2008). No umjesto da STT zajednički razradi kako se pozabaviti s pronađene 34 „vruće točke”, taj je dio posla preuzela konzultantska tvrtka koja je izvorno uključena samo da omogući lakše upravljanje projektom, pa je daljnji napredak zapravo zaustavila sastavljanjem završnog izvješća (Akcijski program poboljšavanja stanja, Remediation Action Programme, RAP), koje se pokazalo nedostatnim te ga je Upravni odbor naposljetku odbacio (Iliso, 2008; Louw, 2009b).

Kako bi se krenulo dalje, pokrenuta je nova inicijativa, ali ovaj put ne samo s predstavnicima vlasti 
tive was started, this time not only involving governmental representatives, as in the first attempt, but also the local mining industry (represented by the specially established Mining Interest Group, MIG), environmental activists (FSE, WWF) as well as the affected municipalities. Having been appointed as expert advisor to the Steering Committee, the author was tasked to develop a remediation strategy for the region. Unfortunately, progress has stalled since mid2011 following the involvement of newly appointed staff from NWU and resulting confusion on the role of the institution in the process (Phillips, 2011; 2012).

Owing to the importance of the matter to the health of people, as well as deliberate efforts of environmental activists to expose the matter, coverage of the U-problem in the media increased significantly. Apart from local weekly newspapers of the area concerned, national daily and weekly newspapers reported on the matter frequently on the front page, allocating up to full double pages to the topic. Later the international news media, including well-known newspapers such as Die Welt (Germany), The Washington Post (USA), Le Monde (France), TV stations (German ZDF/ 3SAT; a Chinese TV station, Al Jazeera), South African prime-time TV shows (Card Blanche, Fokus, Rooi Trok) as well as numerous online media and radio broadcasters from overseas (Canada, Belgium, Netherlands etc.) and South Africa covered the story.

The rise in public awareness following the Brenk Report resulted, amongst other, in the formation of residents-driven interest groups such as the "Wonderfontein Action Group" which - dissatisfied with the lack of governmental action - collaborated with parts of the mining industry in an effort to quantify the degree of sediment pollution (WAG, 2007). The issues in the WFS catchment also initiated the foundation of NGOs such as the Public Environmental Arbiters (PEA) and the Federation for a Sustainable Environment (FSE) - now perhaps the most vocal, active and influential NGO of SA in this field. Largely owing to activities of the latter, the WFS matter was repeatedly tabled in Parliament (e.g. Liefferink, 2008).

Although not located in the WFS catchment, the Tlokwe municipality (formerly Potchefstroom) and kao u prvome pokušaju nego i s predstavnicima lokalne rudarske industrije (koju je predstavljala posebna Rudarska interesna skupina, Mining Interest Group, MIG), ekoloških aktivista (FSE, WWF) i stanovnika ugroženih naselja. Kako ga je Upravni odbor postavio za stručnog savjetnika, autorov je posao bio razvoj strategije poboljšanja stanja u regiji. Nažalost, napredak je sredinom 2011. zaustavljen nakon uključivanja novopostavljenog osoblja NWU-a (North-West University) i zbrke uzrokovane nejasnom ulogom te ustanove u procesu (Phi1lips, 2011, 2012).

Zbog važnosti zaštite zdravlja ljudi i velikih napora ekoloških aktivista problem onečišćenje uranijem sve se češće spominjao u medijima. Osim lokalnih tjednika iz zahvaćenog područja temu su na naslovnicama često isticale i nacionalne dnevne i tjedne novine posvećujući joj mnogo prostora. Priču su poslije iznijeli i strani mediji, među njima i poznate novine, primjerice Die Welt (Njemačka), The Washington Post (SAD), Le Monde (Francuska), TV-postaje (njemački ZDF/3SAT, kineska TV-postaja, Al Jazeera), popularni južnoafrički TV-programi (Card Blanche, Fokus, Rooi Trok) te brojni internetski mediji i radiopostaje iz inozemstva (Kanada, Belgija, Nizozemska itd.) i Južnoafričke Republike.

Sve veća osviještenost javnosti nakon objavljivanja Brenkova izvješća za posljedicu je, između ostaloga, imala i utemeljenje interesnih skupina lokalnog stanovništva poput Akcijske skupine Wonderfontein (Wonderfontein Action Group, WAG), koja je - nezadovoljna djelovanjem vlasti - s dijelom rudarske industrije surađivala u pokušaju kvantificiranja stupnja onečišćenosti sedimenta (WAG, 2007). Problemi u poriječju WFS-a također su potaknuli osnivanje nevladinih organizacija poput Javnih ekoloških arbitara (Public Environmental Arbiters, PEA) i Saveza za održivi okoliš (Federation for a Sustainable Environment, FSE) - danas na tom području možda najglasnije, najaktivnije i najutjecajnije nevladine organizacije u Južnoafričkoj Republici. Uglavnom je zbog njezina rada pitanje WFS-a često bilo na dnevnom redu parlamenta (npr. Liefferink, 2008).

Iako se ne nalazi u poriječju WFS-a, grad Tlokwe (prije Potchefstroom) i sigurnost njegove op-
Uranium pollution in South Africa: past research and future needs

Onečišćenje uranijem u Južnoafričkoj Republici: prošla istraživanja $\mathrm{i}$ buduće potrebe 
GEOGRAFSKI

GLASNIK

77/2,33-53 (2015.) the safety of its water supply soon became a major focal point in media reporting. While the local newspaper originally raised concerns about the problem in line with national media, this later changed and it increasingly assured residents that no problem existed anymore. This largely mirrored the changing attitude of the City Council towards the issue, now claiming that no U-problem existed, conveniently forgetting that, in 2003, it had itself taken legal actions against an upstream gold mine for polluting the town's water resources with U (Anonymous 2010a). In addition to a large (and presumably expensive) public-relation campaign with billboards and flags being placed across the entire town and full-page advertorials in local newspapers proclaiming the safety of its water supply, the City Council also organised a so-called "Water Lekotla" aimed - according to the local newspaper - ...to get closure on the quality of Potchefstroom's water, once and for all while labelling the author as well as the head of research of the Cancer Association of South Africa (CANSA) as sceptics ... whose comments have once again set the cat among pigeons (Anonymous, 2010a). The overall tone of the announcement portrayed the forum as a kind of "show-down" in which the sceptics would be put in their place.

Media reports about the event, however, later portrayed a very different picture and generally agreed that there were legitimate reasons for persisting concerns (e.g. Anonymous, 2010b). Following up on results that indicated ten times higher U-levels in calcite scales of water kettles used in Potchefstroom than in nearby Ventersdorp, which is not affected by mining pollution (Winde, 2003), the Cancer Association of South Africa (CANSA) attempted a survey on U-levels in teeth as possible bio-indicator of $\mathrm{U}$-exposure of residents (Albrecht $\mathrm{C}$, Director of Research of CANSA, personal communication 2012, Beega, 2012a) ${ }^{2}$.

The continued contradictions between reports in local and national news media on the matter further contributed to suspicions held in some quarters that efforts were still being made behind the scenes to obscure the true extent of the problem (Beega, 2008b; Tempelhoff, 2008d). Recently released data of the skrbe vodom uskoro su postali središnjom temom medijskih napisa. Dok su mjesne novine isprva o problemu pisale usklađeno s nacionalnim medijima, to se poslije promijenilo te su sve češce uvjeravale lokalno stanovništvo da problem više ne postoji. To je uvelike odražavalo promjenu stava gradske uprave prema problemu, koja je sad stanovništvo uvjeravala da onečišćavanja uranijem više nema, zaboravljajući da je 2003. baš gradska uprava tužila rudnik zlata smješten uzvodno jer onečišćuje gradske vodene resurse uranijem (anonimni autor, 2010a). Osim opsežne (i vjerojatno skupe) propagandne kampanje s plakatima i zastavama po cijelome gradu te velikim plaćenim člancima u mjesnim novinama koji su hvalili sigurnost vodoopskrbe gradsko je vijeće organiziralo i forum Voda Lekotla (Water Lekotla) kako bi se, prema mjesnim novinama, ,jednom za svagda riješilo pitanje kakvoće vode u Potchefstroomu", nazivajući autora i voditelja istraživanja Južnoafričke udruge za rak (Cancer Association of South Africa, CANSA) „skepticima (...) čiji su komentari ponovno pustili mačku među golubove" (anonimni autor, 2010a). Najavni članak opisivao je forum kao svojevrsni „konačni obračun”u kojem će „skeptici” biti stavljeni na mjesto koje im pripada.

No kasniji medijski napisi o tom zbivanju bili su u posve drukčijem tonu te su se općenito složili da postoje dobri razlozi za zabrinutost (npr. anonimni autor, 2010b). Nadovezujući se na rezultate koji su upućivali na deseterostruko veće razine uranija u kalcitnim naslagama kotlića za vodu u Potchefstroomu od onih u obližnjem Ventersdorpu, nezahvaćenim rudničkim onečišćenjem (Winde, 2003), Južnoafrička udruga za rak (Cancer Association of South Africa, CANSA) pokušala je istražiti razinu uranija u zubima kao mogućeg bioindikatora izloženosti mjesnog stanovništva uraniju (Albrecht C, direktor istraživanja CANSA-e, osobno priopćenje, 2012; Beega, 2012a) ${ }^{2}$

Stalna proturječja među izvješćima mjesnih i nacionalnih medija o toj temi potaknula su dodatne sumnje nekih da se zakulisno pokušava prikriti pravi opseg problema (Beega, 2008b; Tempelhoff, 2008d). Nedavno objavljeni podaci o testiranju vode u Potchefstroomu (Tlokwe Municipality, 2013) po-

2 This survey was unsuccessful due to a lack of co-operation from a local dentist (C Albrecht, personal communication 2012).

2 To istraživanje nije uspjelo zbog izostanka suradnje mjesnog zubara (C. Albrecht, osobno priopćenje 2012.). 
water-monitoring programme of Potchefstroom (Tlokwe Municipality, 2013) indicate a significant rise in U-levels in raw and in tap water - a possibility predicted by the author on various occasions - appear to vindicate the sceptics (Winde, 2013).

In addition to studies dedicated to investigating U-pollution especially in gold mining areas, there were also at least two efforts to determine $U$ levels for non-contaminated streams and groundwater bodies. Kronfeld and Vogel (1991) surveyed 20 rivers across the country while Sami and Druzinski (2003) used geological information to model possible U-levels in selected aquifers (unfortunately without providing concrete U-data). Neither of the two studies addressed the potentially associated pollution hazards.

\section{Assessing the risks of $U$ pollution: a radio-ecological approach}

When John Snow, in 1849, finished a treatise entitled On the mode of communication of cholera, he was the first scientist who establish a link between water quality and human health and indeed to conduct what would later be referred to as an epidemiological study.

At a time when it was common knowledge that epidemics such as cholera, plague and other diseases were caused by the offensive smells riddling the overcrowded industrial towns (e.g. the very term "Malaria" means "bad air") his findings were, however, ignored and even ridiculed. The Lancet, now among the most renowned medical journals, even suggested at the time that Snow was in the pockets of industry that produced such smells and his suggested water pathway was just a "red herring" ${ }^{3}$. It was only after another devastating outbreak of cholera in Soho that killed 500 people in 10 days that Snow's suggestion to remove the handle from a public water pump in Broad Street was followed and the cholera eventually subsided (Bryson, 2004). The fate of Snow's work is one of the many examples for Schopenhauer's three stages of dealing with new insights: at first they are ridiculed, then fought against, and eventually are used by everybody as being self-evident. kazuju znatan porast količine uranija u tekućoj vodi i vodovodu, pa mogućnost koju je autor spominjao u mnogo navrata očito opravdava "skeptike" (Winde, 2013).

Osim istraživanja posvećenih onečišćenju uranijem poglavito u područjima s rudnicima zlata, barem se dvaput pokušalo ustanoviti razine uranija u neonečišćenim tekućicama i podzemnoj vodi. Kronfeld i Vogel (1991) istražili su dvadeset rijeka diljem zemlje, a Sami i Druzinski (2003) upotrijebili su geološke informacije za modeliranje mogućih razina uranija u nekim vodonosnim slojevima (nažalost, bez navođenja konkretnih podataka o uraniju). $\mathrm{Ni}^{-}$ jedno od ta dva istraživanja nije se bavilo mogućim opasnostima povezanim s onečišćivanjem.

\section{Procjena rizika onečišćenja uranijem: radioekološki pristup}

Kad je John Snow 1849. završio traktat „O načinu prijenosa kolere”, bio je prvi znanstvenik koji je utvrdio vezu kakvoće vode i ljudskog zdravlja te je zapravo proveo ono što ćemo poslije nazvati epidemiološkim istraživanjem.

$\mathrm{U}$ to su doba svi znali da je epidemije poput onih kolere, kuge i drugih bolesti uzrokovao smrad u prenapučenim industrijskim gradovima (riječ „malarija” znači „loš zrak”), pa su njegova otkrića zanemarivali, čak i ismijavali. Lancet, danas jedan od najcjenjenijih medicinskih časopisa, čak je napisao da Snowa plaća industrija koja stvara taj smrad te da je njegova teorija o prenošenju vodom samo pokušaj „odvraćanja pozornosti”. ${ }^{\text {. Tek je na- }}$ kon još jednog smrtonosnog izbijanja kolere u londonskom Sohou, u kojem je u deset dana pomrlo petsto ljudi, Snowov prijedlog da se ukloni ručica s javne vodene crpke u Broad Streetu prihvaćen te je kolera naposljetku nestala (Bryson, 2004). Sudbina Snowova rada jedan je od brojnih primjera Schopenhauerovih triju faza suočavanja s novim spoznajama: najprije ih se ismijava, zatim se protiv njih bori, a naposljetku ih svi prihvaćaju jer su tako bjelodane.

3 This reminds the author of a similar reaction by the Mail and Guardian on the 'Winde report' on the absence of flooding risks by underground gold mines in Johannesburg, claiming that the report was a 'ruse' to downplay risks and polish the image of business in the city.

3 To autora podsjeća na sličnu reakciju Maila i Guardiana na „Izvješće Winde” o nepostojanju opasnosti od potapanja podzemnih rudnika zlata u Johannesburgu, koji su tvrdili da je izvješće bilo „smicalica” za umanjivanje opasnosti i uljepšavanje predodžbe o gradskoj industriji. 
HRVATSKI

GEOGRAFSKI

GLASNIK

77/2,33-53 (2015.)
The approach that allowed Snow to discover the link between polluted water and health problems was essentially geographic in nature and largely based on analysing spatial patterns. Investigating the geographic occurrence of cholera deaths, which finally pointed to Broad Street as source of the problem, Snow's attention was drawn to two odd cases of deaths that occurred kilometres away from there. After hiking out to these sites and talking to relatives and neighbours - in today's terms conducting a reconnaissance study with semi-structured interviews - he realised that in both cases water from Broad Street had been actually brought there - confirming results of his earlier spatial analysis (Bryson, 2004).
Pristup koji je Snowu omogućio da otkrije vezu onečišćene vode i zdravstvenih tegoba u načelu je bio geografski, utemeljen uglavnom na analizi prostornih obrazaca. Istražujući geografsku pojavnost smrti uzrokovanih kolerom koja je naposljetku uputila na Broad Street kao izvor problema, Snowovu su pozornost privukla dva neobična slučaja smrti koja su se zbila kilometrima daleko jedan od drugoga. Nakon što je otišao do njih i razgovarao s rođacima i susjedima (danas bismo to nazvali terenskim istraživanjem s polustrukturiranim intervjuima), shvatio je da je u oba slučaja voda donesena iz Broad Streeta, čime je potvrdio rezultate svoje prostorne analize (Bryson, 2004).

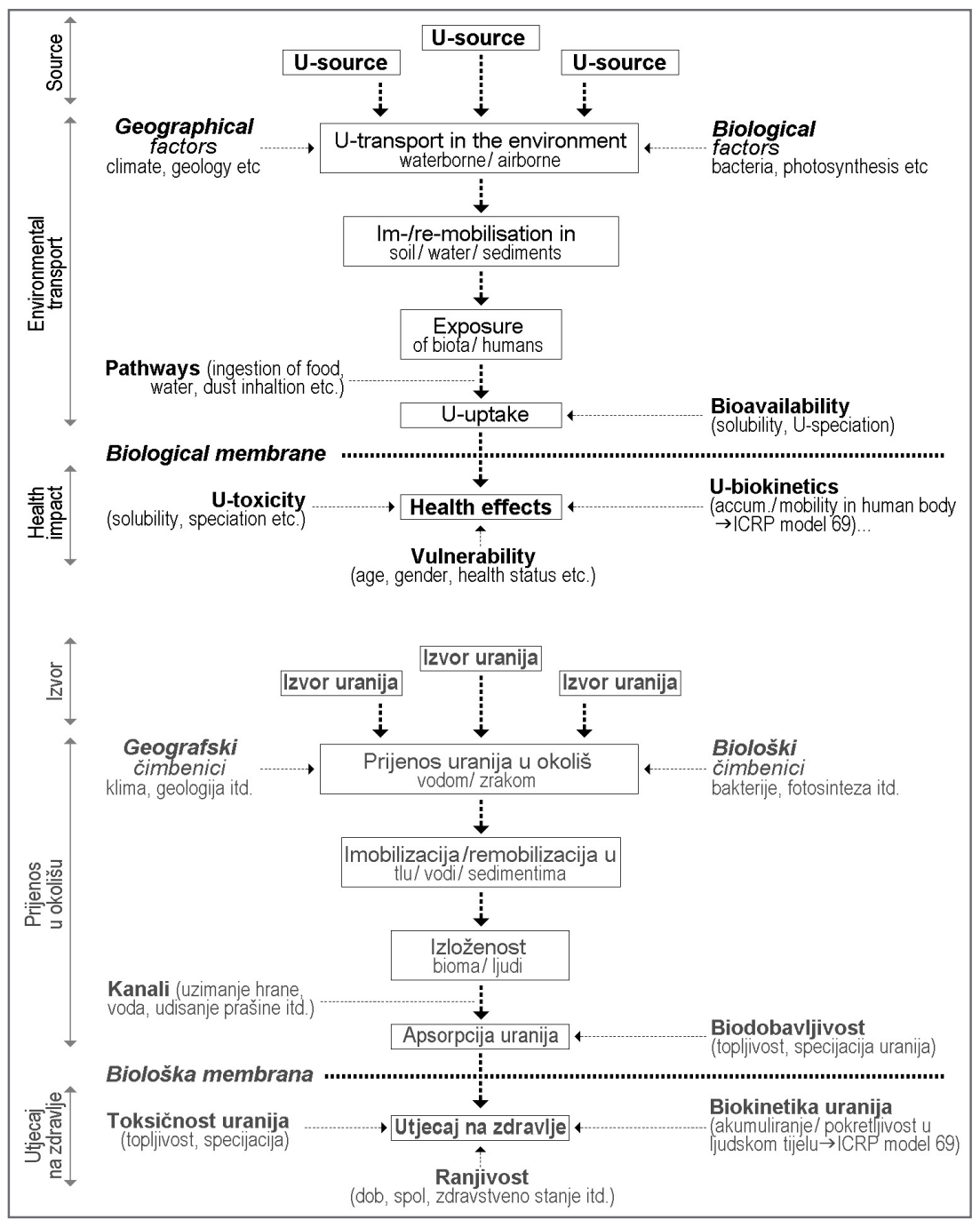

Fig. 2 Model of the radio-ecological approach to assessing risks associated with U-pollution (after an idea of Salbu, 2009)

SI. 2. Model radioekološkog pristupa procjene rizika povezanog s onečišćenjem uranijem (prema Salbuovo) zamisli, 2009.) 
Risk is commonly defined as the probability at which a hazard may translate into real damage. In the context of assessing health risks associated with U-pollution, this means quantifying the existing hazard (i.e. the health damage potential and extent of U-pollution) and the probability that humans will be adversely affected. Linking pollution sources to receptors by investigating the pathways along which a contaminant moves through the environment is at the core of geo-ecology, also termed "radio-ecology" when radioactive substances are concerned (Salbu, 2009). The model underlying the radio-ecological approach is depicted in Fig. 2.

\section{Source term characterisation}

In order to quantify a contamination hazard, two major aspects are to be considered: the concentration of the pollutant and its quantity.

Concentration refers to the mass, or volume of contaminants relative to the mass/volume of the media in which they occur. Generally, associated risks increase the higher the concentrations since, for example, the ingestion of contaminated media result in relative large quantities of the contaminant entering the body. Furthermore, large differences in concentration between the contaminated site and the surrounding environment create geochemical gradients promoting the dispersion of the contaminant.

Quantity of the contaminant refers to the total mass/volume of a contaminant in a certain area of concern. Considering this aspect is important as high contaminant concentrations in very minute quantities may not pose a problem, while less high concentrations occurring in very large quantities may.

In order to reduce environmental and health risks, maximum allowable concentrations are legislated for the various types of contaminants. If these limits are exceeded in certain material, special precaution must be taken such as deposition in specially designed waste disposal sites.

\section{Contaminant transport in the environment}

The transport aspect is also termed "environmental mobility" or "environmental fate" and refers to the ability of a pollutant to move from a source through
Rizik se često definira kao vjerojatnost po kojoj će se opasnost pretvoriti u stvarnu štetu. U kontekstu procjene zdravstvenih rizika povezanih s onečišćenjem uranijem to znači kvantificiranje postojeće opasnosti (tj. potencijala narušavanja zdravlja i raširenosti onečišćenja uranijem) i vjerojatnosti da će to naškoditi ljudima. Povezivanje izvora onečišćenja $s$ receptorima istraživanjem kanala širenja onečišćivača okolišem sama je bit geoekologije, koju se kad je riječ o radioaktivnim tvarima još naziva „radioekologijom" (Salbu, 2009). Model na kojem počiva radioekološki pristup prikazan je na sl. 2 .

\section{Definicija izvornih pojmova}

Kako bi se mogla kvantificirati opasnost od onečišćenja, valja razmotriti dva glavna čimbenika: koncentraciju onečiščivača i njegovu količinu.

Koncentracija se odnosi na masu, odnosno obujam onečišćivača prema masi/obujmu sredstva u kojem se pojavljuje. Općenito, rizici se povećavaju s višim koncentracijama jer primjerice gutanje onečišćenog sredstva znači unošenje razmjerno velikih količina onečišćivača u tijelo. Usto, velike razlike u koncentraciji između onečišćenog lokaliteta i okolnog područja stvaraju geokemijske gradijente koji potiču širenje onečišćivača.

Količina onečišćivača odnosi se na ukupnu masu/ obujam onečišćivača u promatranom području. Istražiti taj aspekt važno je jer visoke koncentracije onečišćivača u vrlo malim količinama ne moraju predstavljati problem, dok manje koncentracije u vrlo velikim količinama mogu.

Kako bi se smanjili ekološki i zdravstveni rizici, za različite vrste onečišćivača propisane su najveće dopuštene koncentracije. Ako se u nekome materijalu te granice prekorače, valja poduzeti posebne mjere poput odlaganja na posebna odlagališta.

\section{Prijenos onečišćivača u okoliš}

Prijenos se naziva još i „ekološka pokretljivost” ili „ekološka sudbina”, a odnosi se na mogućnost prelaska onečišćivača iz izvora kroz različita sredstva u okoliš, primjerice vodu, tlo ili zrak, prema receptoru ili spremniku.
Uranium pollution in South Africa: past research and future needs

Onečišćenje uranijem u Južnoafričkoj Republici: prošla istraživanja $\mathrm{i}$ buduće potrebe 
GEOGRAFSKI

GLASNIK

77/2,33-53 (2015.) various environmental media such as water, soil or air towards a receptor or sink.

Since the concept of mobility is sometimes used ambiguously, a distinction between "physical" and "chemical mobility" is useful. While the former refers to the physical transport of $U$ in whatever form - as particle, colloid, or dissolved - the concept of "chemical mobility" commonly refers to differences between solid phases regarded as rather immobile [e.g. precipitates] and more mobile dissolved phases of a specific contaminant. Changes from dissolved to solid phases are thus referred to as "immobilisation" with the reverse processes termed "re-mobilisation" (Fig. 2). If a contaminant is immobilised in a repository, for example. as a solid phase contained in sediment, or soil, these repositories are termed "sinks" - lowering the mobile amount of the contaminant in the environment.

\section{Health impacts on exposed humans}

This aspect refers to the damage which contaminants cause that finally impact on exposed organisms/ humans ("receptors"). The degree to which organisms are affected depends on the actual health damage potential of the contaminant (toxicity), the extent of contact between the receptor and the contaminant (exposure), the ease at which the contaminant can enter the organism (bioavailability), and lastly, the vulnerability of the affected receptor (Fig. 2).

Toxicity depends not only on the toxic properties of the actual element of concern but also on the various compounds, or species a contaminant may form that are able to alter its properties, as well as its solubility changing its biokinetical behaviour and effects inside the organisms. Guidelines stipulating acceptable levels for certain contaminants are generally based on their toxicity. In many cases, toxicity was determined not by epidemiological studies on humans but by animal experiments using certain species such as small mammals like rodents, mice and rabbits, and extrapolating the results. While such extrapolation of results from animals to humans is successful in many cases, medical history also records cases where this approach failed spectacularly and resulted in enormous human suffering (e.g. the Contergan scandal in Germany) (Hartung 2010, Kolukisaoglu et al., 2010).
Kako se pojam pokretljivosti katkad upotrebljava neodređeno, korisno je uvesti razliku fizikalne i kemijske pokretljivosti. Dok se prvi pojam odnosi na fizički prijenos uranija u bilo kojem obliku - kao čestica, koloida ili otopljenoga - pojam kemijske pokretljivosti obično se odnosi na razlike između krute faze, koju se smatra razmjerno nepokretnom i pokretljivije otopljene faze određenog onečišćivača. Promjene iz otopljenih u krute faze nazivaju se imobilizacija, a obrnuti proces remobilizacija (sl. 2). Ako je onečišćivač imobiliziran u spremniku, primjerice kao kruta faza u sedimentu ili tlu, takve spremnike nazivamo „izljevima”, koji smanjuju količinu pokretnog onečišćivača u okolišu.

\section{Utjecaj na zdravlje izloženih ljudi}

Taj se aspekt odnosi na štetu koju onečišćivači uzrokuju i naposljetku djeluju na izložene organizme/ljude (,receptori”). Stupanj u kojem su organizmi ugroženi ovisi o stvarnom potencijalu ugrožavanja zdravlja onečišćivača (toksičnost), opsegu kontakta receptora i onečišćivača (izloženost), lakoći s kojom onečišćivač može ući u organizam (biodobavljivost) i naposljetku ranjivosti receptora (sl. 2).

Toksičnost ne ovisi samo o toksičnim svojstvima tvari o kojoj je riječ nego i o različitim spojevima ili vrstama onečišćivača koje mogu nastati i promijeniti mu svojstva i topljivost te tako izmijeniti biokinetičko ponašanje i učinke u organizmima. Smjernice o prihvatljivim razinama nekog onečišćivača općenito se temelje na njihovoj toksičnosti. U mnogo slučajeva toksičnost nije određena epidemiološkim istraživanjem na ljudima, nego pokusima na životinjama, obično određenim vrstama poput malih sisavaca, primjerice glodavaca, miševa i kunića, uz ekstrapolaciju rezultata. Iako su takve ekstrapolacije rezultata sa životinja na ljude često prikladne, medicinska povijest bilježi i slučajeve kad se takav pristup pokazao katastrofalno lošim te je za posljedicu imao strašne ljudske patnje (npr. skandal s Conterganom - talidomidom - u Njemačkoj) (Hartung, 2010; Kolukisaoglu i dr., 2010).

Pojam izloženosti receptora odnosi se na kontakt onečišćivača s receptorom, a različite načine 
The term exposure of receptors refers to the contact between contaminant and receptor while the various manners and media via which this occurs are referred to as exposure pathways and include, for example, the consumption/ingestion of contaminated water and food, the inhalation of dust etc. In many instances it is useful to distinguish between "potential" and "realistic" exposure pathways for quantifying associated risks. While "potential" pathways refer to theoretical contact possibilities that cannot be excluded, "realistic" pathways have a much higher probability of occurring. In order to quantify the probability of realistic exposure, statistical values, such as average water consumption etc., are often used in risk assessments.

Bio-availability generally increases with higher solubility of contaminants as dissolved phases are generally more readily absorbed than solid compounds. Solubility, in turn, is often governed by the type of chemical compound a contaminant forms ("speciation") as well as the physico-chemical conditions of the surrounding environment.

Vulnerability refers to the sensitivity of an organism to a particular toxin. While most guidelines aim to include differences in vulnerability of humans due to age or gender when setting values for maximum allowable concentrations, all limits are generally designed for a healthy population (i.e. not considering the more vulnerable, or sick persons) and do not take individual hypersensitivity into account. Moreover, guidelines (for example for toxins in water) are commonly set based on statistically quantified behavioural pattern of the targeted society (such as the average water consumption) assuming a certain diet and "normal" socio-cultural habits. Since such factors may vary significantly between societies of differing economic development levels (e.g. first vs. third world) and cultural identities (East vs. West vs. South) the frequently practised application of guideline values from other (mainly developed) countries in the West may not always be appropriate for the less developed or culturally different societies (Schonfeldt et al. 2015).

In conclusion, it is proposed to employ a systematic radio-ecological approach to assessing the risks associated with the vast amounts of uraniferous tailings and other mining legacy sites currently affecting some of the most densely populated areas in South Africa. An improved understanding of the sources of $U$ in the i sredstva preko koji dolazi do kontakta nazivamo kanalima izloženosti. Oni primjerice uključuju pijenje onečišćene vode ili uzimanje hrane, udisanje prašine itd. U mnogo je slučajeva pri kvantificiranju povezanih rizika korisno razlikovati potencijalne $i$ stvarne kanale izloženosti. Dok se potencijalni kanal odnosi na teoretsku mogućnost kontakta koju se ne može isključiti, za stvarne kanale mnogo je veća vjerojatnost da će biti upotrijebljeni. Kako bi se kvantificirala statistička vjerojatnost stvarnoj izloženosti, u procjeni rizika često se upotrebljavaju čimbenici poput prosječne potrošnje vode.

Biodobavljivost se općenito povećava s većom topljivošću onečišćivača jer je otopljene faze općenito lakše apsorbirati od krutih tvari. Topljivost često ovisi o tipu kemijskog spoja koji onečišćivač stvara (specijacija), ali i fizikalno-kemijskim uvjetima u okolišu.

Ranjivost označuje osjetljivost organizma na određeni toksin. Iako većina smjernica pri određivanju najvećih dopuštenih koncentracija nastoji uključiti razlike u ranjivosti ljudi različitih dobi ili spola, sve se granice općenito odnose na zdravu populaciju (dakle isključuju ranjivije ili bolesne osobe) te ne uzimaju u obzir moguću osobnu preosjetljivost. Usto, smjernice (primjerice za toksine u vodi) obično se postavljaju na statistički kvantificiranom obrascu ponašanja ciljane zajednice (npr. prosječna potrošnja vode) uz pretpostavke o određenom načinu prehrane i „normalnim” društveno-kulturnim navikama. Kako ti čimbenici mogu biti vrlo različiti među društvima različitih razina gospodarskog razvoja (npr. razvijene zemlje u usporedbi s onima Trećeg svijeta) i kulturoloških identiteta (Istok nasuprot Zapadu nasuprot Jugu), često upotrebljavana primjena vrijednosti smjernica iz drugih (uglavnom razvijenih) zemalja Zapada ne mora uvijek biti prikladna za manje razvijena ili kulturološki različita društva (Schonfeldt i dr., 2015).

Kao zaključak predlaže se uporaba sustavnoga radioekološkog pristupa procjeni rizika povezanih s golemim količinama uranijskonosne jalovine $i$ drugih rudničkih lokaliteta koji ugrožavaju neka od najgušće naseljenih područja u Južnoafričkoj Republici. Bolje razumijevanje izvora uranija $u$ obliku sveobuhvatnoga, georeferentnog popisa bio
Uranium pollution in South Africa: past research and future needs

Onečišćenje uranijem u Južnoafričkoj Republici: prošla istraživanja $\mathrm{i}$ buduće potrebe 
GEOGRAFSKI

GLASNIK

77/2,33-53 (2015.) form of a comprehensive, geo-referenced inventory would be a first step towards developing a strategy to systematically address the problem. Since hazard potential only translates into health risks once humans are indeed exposed to elevated U levels and intake, it is important to investigate how $\mathrm{U}$ is dissipated through the environment and which factors govern its chemical and physical mobility. Based on such knowledge cost-effective intervention measures can be designed for scenarios where source-control is not possible or feasible by intersecting transport pathways for minimising exposure of humans and sensitive environmental goods such as water, soil and food.

\section{Summary and conclusion}

Globally, as well as locally in South Africa, research into on environmental and health aspects of U started relatively late, several decades after industrial-scale mining and production of $U$ commenced in the late 1940s. While attempts in the USA to remediate the legacy effects of widespread U-mining of the Cold War period started in the early 1980s, it took another two decades or so before the issue was acknowledged as a problem in South Africa.

A major reason for this delay was a general climate of denial and secrecy still prevailing in the mining industry after decades of confidentiality surrounding all aspects of producing $U$ for the nuclear arms race. With mounting evidence on the extent and risks of U-contamination, especially in the gold mining areas of the Witwatersrand, it was only in the last 5 to 10 years or so that the mining industry was no longer contesting the matter. Interestingly, resistance to acknowledging the problem seems to be even higher at some regulatory authorities such as the Department for Water Affairs and Sanitation and the National Nuclear Regulator, which frequently issue downplaying reports and comments. This attitude may explain why there is still no governmental strategy or effort to systematically address the U-legacy as it was implemented in the USA, Germany and many other former U-producing countries.

In view of the recently announced nuclear expansion programme of South Africa and its renewed ambitions to become once again a major global supplier of $\mathrm{U}$, it becomes even more important for gov- bi prvi korak prema razvoju strategije sustavnog pristupa problemu. Kako se potencijalna opasnost pretvara u zdravstveni rizik tek kad se ljudi doista izlože povećanim razinama uranija i on uđe u organizam, važno je istražiti kako se uranij širi okolišem te koji čimbenici utječu na njegovu kemijsku i fizikalnu pokretljivost. $\mathrm{Na}$ temelju tih spoznaja mogu se osmisliti troškovno učinkovite mjere za scenarije u kojima nadzor nad izvorima nije moguć ili primjeren, prekidajući transportne kanale kako bi se izloženost ljudi i osjetljivih dijelova prirode poput vode, tla i hrane svela na najmanju mjeru.

\section{Sažetak i zaključak}

U svijetu, baš kao i u Južnoafričkoj Republici, istraživanja ekoloških i zdravstvenih posljedica onečišćenja uranijem počela su razmjerno kasno, nekoliko desetljeća nakon što su potkraj četrdesetih godina 20. stoljeća počeli industrijsko rudarenje i proizvodnja uranija. Iako su pokušaji uklanjanja štete uzrokovane rudarenjem uranija tijekom Hladnoga rata počeli početkom osamdesetih, moralo je proći još dvadesetak godina da se to u Južnoafričkoj Republici prihvati kao problem.

Glavni razlog za to zakašnjenje opće je ozračje poricanja i skrivanja koje i danas prevladava u rudarskoj industriji nakon desetljeća tajnosti nametnute svim oblicima proizvodnje uranija za utrku u nuklearnom naoružanju. Zbog sve više dokaza o raširenosti i opasnosti onečišćenja uranijem, osobito u području Witwatersranda, tek u posljednjih pet do deset godina rudarska industrija više ne poriče stanje. Zanimljivo, otpor priznavanju problema čak je veći u nekim regulatornim Vladinim ustanovama poput Ministarstva voda i zdravstva te Državne nuklearne regulatorne agencije, koji često objavljuju ublažena izvješća i komentare. Takav stav može objasniti zašto još ne postoji Vladina strategija ili napor da se sustavno pristupi problemu kao što je to učinjeno u SAD-u, Njemačkoj i mnogim drugim državama u kojima se nekoć proizvodio uranij.

U svjetlu nedavno najavljenog širenja nuklearnog programa u Južnoafričkoj Republici i obnovljenih nastojanja da ponovno postane veliki svjetski dobavljač uranija još je važnije da Vlada dokaže da 
ernment to demonstrate its ability to effectively address historical contamination in order to regain the trust of affected citizens and foreign investors alike.

Adopting a sound scientific approach to the problem by inventarising legacy sites, reliably assessing associated risks and prioritizing remediation needs based on comprehensive radio-ecological research, rather than standard applications of (contested) guideline values, would be a first step towards a systematic solution of the problem.

\section{Professional Terms Editing: Ivan Čanjevac, PhD}

Translation: Ruđer Jeny je sposobna učinkovito riješiti problem povijesnog onečišćenja kako bi vratila povjerenje zahvaćenog stanovništva, ali i stranih ulagača.

Prihvaćajući ispravni znanstveni pristup problemu, popisujući onečišćena mjesta, pouzdano procjenjujući s tim opasnosti i određujući prioritete djelovanja na temelju sveobuhvatnih radioekoloških istraživanja, a ne uobičajenom primjenom (osporavanih) smjerničkih vrijednosti, učinila bi prvi korak prema sustavnom rješavanju problema.

Stručna redaktura: dr. sc. Ivan Čanjevac Prijevod: Ruđer Jeny
Uranium pollution in South Africa: past research and future needs

Onečiščenje uranijem u Južnoafričkoj

Republici: prošla istraživanja $\mathrm{i}$ buduće potrebe
Anonymous, 2010a: Yes, you can drink it, Potchefstroom Herald 1 October 2010, 3.

Anonymous, 2010b: Drinkwater veilig, inwoners nie oortuig. (Drinking water safe, residents not convinced.), NorthWest Independent, 2 February 2010, front page.

Avni, J., 2007: Death in the water. Millions of people drink and bathe in poisoned water flowing from the mines, Sowetan 24 July 2007, Cover page and 4.

Bain, C. A. R., Schoonbee, H. J., de Wet, L. P. D., Hancke, J. J., 1994: Investigation into the concentration ratios of selected radionuclides in aquatic ecosystems affected by mine drainage effluents with reference to the study of potential pathways to man. WRC report no. 313/1/94, Pretoria.

Barthel, R., 2007: Assessment of the Radiological Impact of the Mine Water Discharges to Members of the Public Living around Wonderfonteinspruit Catchment Area. BSA Project No. 0607-03, BS Associates, Consulting Engineers and Scientists. Report to the National Nuclear Regulator (NNR), Contract No. RRD/RP01/2006, Bedfordview, unpublished.

Barthel, R., Deissmann, G., Leotwane, W., 2007: Radiological impact assessment of mining activities in the Wonderfonteinspruit catchment area (accepted abstract), Environmental Conference, Pilanesberg, July 2007, South Africa.

Barthel, R., 2011: Radiological impact assessment of mining activities in the Wonderfonteinspruit catchment area,
South Africa, in: Merkel, B. J., Schipek, M. (eds.): The new uranium mining boom, DOI 10.1007/978-3-642-22122-4, Springer, Berlin-Heidelberg, 517-528.

Beega, S., 2008a: Living in fear of a toxic tsunami. Far West Rand residents claim poisoning, Saturday Star, 12 April 2008, full page article.

Beega, S., 2008b: Pollution problem played down, Saturday Star, 27 September 2008.

Beega, S., 2012a: Teeth hold the clues to Potchefstroom's future, Saturday Star, 22 December 2012, 4.

Botha, C., 2008: Toxic shock. Onions from Twitcher's Eden were tested by Necsa and found to contain levels of radioactivity above acceptable levels, Potchefstroom Herald, 8 February, 3.

Bryson, B., 2004: At home - a short history of private life, Transworld Publishers, London, 514-516.

Cerne, M., Smodis, B., Strok, M., 2010: Uptake of radionuclides by a common reed (Phragmites australis (Cav.) Trin. ex Steud.) grown in the vicinity of the former uranium mine at Žirovski vrh, Nuclear Engineering Design 241 (4), 1282-1286.

Chamber of Mines, 1999: Table of Uranium concentrations in slimes dams of South African goldmines - based on the uranium concentration in ore, the amount of milled ore and the extend of extracted uranium (as reported to the Chamber of Mines of South Africa, compiled by Wymer, D.), unpublished, Johannesburg.

COMRO, 1985: Sub-committee on mine water pollution - circular no. $7 / 85$, unpublished.

Die Komitee oor die Gehalte van Water aan die Verre-Wesrand, 1971: Finale verslag oor vermoedlike skade deur mynwaters aan diere en gewasse in die Oberholzer-besproeiingsgebied aan sy edele die minister van mynwese Dr. C. de Wet. [Final report on possible damage to animals caused by mine water in the Oberholzer irrigation area to the Honourable Minister of Mining Dr. C. de Wet], Augustus 1971, confidential, Pretoria.

Deelkraal, G. M., 1995: Pilot study to determine uranium levels in urine of underground workers at Deelkraal gold mine, Internal report, unpublished.

Dorling, D., 1988: Uranium concentrations in selected mine waters from Randfontein Estate Gold Mine (REGM), analytical results, unpublished.

Engelbrecht, P., 2008: Leuens, se boere [Lies, say farmers], Potchefstroom Herald, 8 February, 2.

Faanhof, A., van Veelen, M., Pulles, W., 1995: Radioactivity in water sources: a preliminary survey, DWAF Report No. N/0000/00/REQ/0695, Department of Water Affairs and Forestry, Pretoria.

Funke, J. W., 1990: The water requirements and pollution potential of South African gold and uranium mines, WRC report, Pretoria.

\section{Note \\ Napomena}

\section{Literature} Literatura 
GEOGRAFSKI

GLASNIK

77/2,33-53 (2015.)
Hamman, D., 2012: A holistic view on the impact of gold and uranium mining on the Wonderfonteinspruit, Dissertation for the degree Master of Science in Environmental Science, North-West University, unpublished.

Hartung, T., 2010: Food for thought ... on alternative methods for chemical safety testing, http://www.altex.ch/resources/ altex_fft_hartung_1_10.pdf, 2/2015.

Iliso (Consulting Ltd.), 2008: Wonderfonteinspruit catchment area remediation plan, Report to Department of Water Affairs and Forestry and National Nuclear Regulator, 1st draft.

IWQS (Institute for Water Quality Studies), 1999: Report on the radioactivity monitoring programme in the Mooi River (Wonderfonteinspruit) catchment, Report no N/C200/00/RPQ/2399, Department of Water Affairs and Forestry, Pretoria, unpublished.

Jordaan, J. M., Enslin, J. F., Kriel, J. P., Havemann, A. R., Kent, L. E., Cable, W. H., 1960: Final Report of the Interdepartmental Committee on Dolomitic Mine Water: Far West Rand, DWA report, DWA, Pretoria, unpublished.

Jordan, B., 2009: Toxic water poses health nightmare, Sunday Times, 19 July.

Kempster, P. L., van Vliet, H. R., Looser, U., Parker, I., Silberbauer, M. J., du Toit, P., 1996: Overview of radioactivity in water sources: uranium, radium and thorium, Final report, IWQS-No: N/0000/00/ RPQ/0196, Pretoria.

Kolukisaoglu, Ü.,Wendler, C., Goerdes, D., Diener, A., Thurow, K., 2010: Inhibitory effects of phthalimide derivatives on the activity of the hepatic cytochrome P450 monooxygenases CYP2C9 and CYP2C19, Journal of Enzyme Inbibition and Medicinal Chemistry 25 (6), 876-886.

Kronfeld, J., Vogel, J. C., 1991: Uranium isotopes in surface waters from southern Africa, Earth and Planetary Science Letters 105, 191-195.

Liefferink, M., 2008: Oral submission on behalf of the Federation of sustainable Environment to the Parliamentary Portfolio Committee on Water Management and Pollution, 4 June 2008.

Louw, A., 2009: Wonderfontein cleanup plan 'seriously flawed', Carletonville Her- ald, 14 August, 5.

Martins, M., 2008: Moet inwoners maskers dra? Carletonville Herald, 23 May, 11.

McCrindle, 2008: Preliminary results from analysing water, sediments, milk and cattle tissue for uranium and other metals in the Wonderfonteinspruit catchment, 45 tissues samples, Technical University of Pretoria, unpublished.

Olivier, M., 2007: DME finalises national nuclear strategy, Mining Weekly online, 14 February 2007

Phillips, O., 2011: Letter of the chairman of the Remediation Steering Committee Mr. O. Phillips (National Nuclear Regulator) to the Vice-chancellor of the North-West University (Dr. T. Eloff): Request for collaboration by Remediation Steering Committee, 30 June 2011.

Phillips, O., 2012: Minutes of the Regulators meeting regarding Wonderfonteinspruit catchment area remediation, Date of meeting: 20 February 2012, National Nuclear Regulator, Centurion.

Pulles, W., 1991: Radionuclides in South African gold mining water circuits: an assessment of licensing, health hazards, water and waste water regulations and impact on the environment and workforce, COMRO, restricted report no. 17/91, Programmes reference GE1C, Chamber of Mines, Johannesburg.

Robb, V. M., Robb, L. J., 1998: Environmental impact of Witwatersrand gold mining, in: Wilson, M. G. G., Anhaeusser, C. R. (eds.): The mineral resources of South Africa, Sixth edition, Handbook 16, Council for Geoscience, Pretoria (Silverton), 14-17.

Salbu, B., 2009: Challenges in radioecology, Journal of Environmental Radioactivity 100, 1086-1091.

Sami, K., Druczinski, A. L., 2003: Predicted spatial distribution of naturally occurring arsenic, selenium and uranium in groundwater in South Africa - reconnaissance survey, WRC report no. 1236/1/03, Water Research Commission, Pretoria.

Schonfeldt, S. J., Winde, F., Albrecht, C., Kielkowski, D., Liefferink, M., Patel, M., Stoch, L., Whitaker, C., Schüz, J., 2014: Health effects in populations living around the uraniferous gold mine tailings in South Africa: gaps and op- portunities for research, Cancer Epidemiology 38, 628-632.

Sekoko, I., Mafejane, A., Potgieter, D., Conradie, B., Kempster, P., Kühn, A., Diefenbach, A., 2005: A survey on the radiological and chemical quality of water resources in selected sites of the Northern Cape Province, Resource Quality Service Report No. N/0000/GEQ0603, Final Report, unpublished.

Stoch, E. J., Retief, J., 1967: Memorandum of farmers on adverse effects associated with mine water on the health of farm animals, Private archive of E. J. Stoch, Welverdiend, unpublished.

Stoch, E. J., 2008: Don't believe everything you read, Published letter in Carletonville Herald, 30 May.

Stuijt, A., 2008: SA radioactive stream 400,000 at high risk, http://www.rense. com/general77/sarad.htm, accessed 5.5.2008

Taverner, L., 1957: An historical review of the events and developments culminating in the construction of plants for the recovery of uranium from gold ore residues, in: Uranium in South Africa 1946-1956, Volume 1: Proceedings of a joint symposium of the Associated Scientific E Technical Societies of South Africa, Hortors 1td., Johannesburg, 1-19.

Tempelhoff, E., 2007a: Mynmonopolie se grumoeras, Beeld, 2 February 2007, 11.

Tempelhoff, E. 2007b: Duisende beeste dalk geskiet oor besoedeling [Thousands of cattle shot because of pollution], Beeld, 29 November 2007.

Tempelhoff, E., 2008a: 'Dra maskers in Wonderfontein' ['Use masks in Wonderfontein'], Beeld, 7 May, 5.

Tempelhoff, E., 2008b: 'Giftstof in kos skok - radioaktiewe stowwe in voedselketting, ['Poison in food shock - radioactive susbtances in foodchain'], Beeld, 2 February, frontpage.

Tempelhoff, E. 2008c: 'G'n radioaktiewe stowwe in kos, reken reguleerder ['No radioactive substances in food, reckons regulator'], Beeld, 8 February, 10.

Tempelhoff, E. 2008d: Regering mislei publiek' oor Wonderfonteinspruit se veiligheid ['Government misleads public over Wonderfonteinspruit's safety], Beeld, 23 September. 
Tlokwe Municipality, 2013: Results of the municipal water monitoring programme $\mathrm{Feb} .2012$ - Feb. 2013, Unpublished analytical data, Potchefstroom.

Toens, P. D., Stadler, W., Wullschlege, N. J., 1998: The association of groundwater chemistry and geology with atypical lymphocytes (as biological indicator) in the Pofadder area, WRC report 839/1/98, North Western Cape.

Van Heerden, D., 2007: Experts say water is safe, for now, Potchefstroom Herald, 14 December.

Van Wyk, Coetzee, H. 2008: The distribution of uranium in groundwater in the Bushmanland and Namaqualand areas, Northern Cape Province, South Africa, in: Merkel, B. J., Hasche-Berger, A. (eds.): Uranium mining and hydrogeology, Springer, Berlin and Heidelberg, 639644.

Waggit, P., 1994: A review of worldwide practices for disposal of uranium mill tailings, Technical Memorandum 48, Supervising Scientists for the Alligator Rivers Region, reprint, Jabiru.
WAG (Wonderfonteinspruit Action Group), 2007: Concentrations of $U$ and other heavy metals in sediments of the lower Wonderfonteinspruit catchment-results. unpublished data provided by BIGEN Africa.

Winde, F., 2003: Comparative study on $U$-levels in calcite scales of water kettles in Potchefstroom and Ventersdorp, Analytical data, unpublished.

Winde, F., 2008: Development of a map ranking sites with known radioactive pollution in the Wonderfonteinspruit catchment according to the urgency of required intervention ('Intervention site map') Underlying methodology and results, Confidential report to Joint Coordinating Committee of the Department of Water Affairs and Forestry (DWAF) and the National Nuclear Regulator (NNR), DWAF. Pretoria, unpublished.

Winde, F., Sandham, L. A., 2004: Uranium pollution of South African streams - an overview of the situation in gold mining areas of the Witwatersrand. Sustainable Water Management in Africa - Chances and Barriers, Supplement volume,
GeoJournal 61 (3), 139-149.

Winde, F., 2013: Uranium pollution of water-a global perspective on the situation in South Africa, Scientific contribution, series H: Inaugural lecture no 10/2013, 55.

Wullschleger, N. J., Visser, D., Stadler, W., 1998: Groundwater health hazards of selected settlements in the province of the Northern Cape, Report to the DWAF, Toens and Partners, Cape Town, unpublished.

Zhuwakinyu, M., 2007: Minister envisages uranium mining, enrichment, fuel making and even processing of spent fuel elements in SA, Mining Weekly online, www.mining-weekly.com, published 5 October 2007.

Zoriy, P., Ostapczuk, P., Dederichs, H., Höbig, J., Lennartz, R., Zoriy, M., 2010: Biomonitoring of environmental pollution by thorium and uranium in selected regions of the Republic of Kazakhstan, Journal of Environmental Radioactivity 101, 414-420. 